\title{
Indicators for assessing state fiscal policy in the context of promoting sustainable development
}

\author{
Olena Sushkova ${ }^{1}$, Viktoriya Hurochkina ${ }^{2}$,Viktoria Voroshilo $^{3}$, and Elena Tumanova ${ }^{3}$ \\ ${ }^{1}$ University of the State Fiscal Service of Ukraine, Department of Customs, 08201 Irpin, Ukraine \\ ${ }^{2}$ University of the State Fiscal Service of Ukraine, Department of Enterprise Economics, 08201 Irpin, \\ Ukraine \\ ${ }^{3}$ V. I. Vernadsky Crimean Federal University, Department of Finance and Credit, 95000 Simferopol, \\ Ukraine
}

\begin{abstract}
The article proposes a scientific and methodological approach to assessing the level of promotion of fiscal policy of sustainable development, uniting a set of indicators of realization in the country of 17 SDGs. Applying the principle of the hierarchy of diagnostic knowledge, the assessment of the level of support for fiscal policies for sustainable development is presented through the linguistic variable, with the separation of measures of influence on the economic, social and environmental blocs. The hierarchical relationship between the state parameters and the level of support for fiscal policies for sustainable development is graphically presented as a logical inference tree The approach has been tested by measuring the level of promotion of fiscal policies for sustainable development in Ukraine for two scenarios, This will make it possible to predict the impact of the country's policies. According to the results of the study, it has been proved that the level of support for the fiscal policy of sustainable development in Ukraine suppresses the implementation of 17 SDGs, and the nature of the changes tends to a pessimistic development scenario, and the total index for promoting fiscal policies for sustainable development decreases annually.
\end{abstract}

\section{Introduction}

The acceleration of the implementation of 17 SDGs to establish a global policy of sustainable growth is made possible by the stimulating effect of fiscal instruments on economic growth. Fiscal policy, as the fundamental foundation of a national economic model, creates the prerequisites for a sustainable development system, is at the same time a key driver in balancing the interests of the State and society. Fiscal regulation, which is an indirect form of government regulation in the context of sustainable development, has a lasting effect and aims at stabilizing the economy and creating conditions for economic growth, social equity through the reallocation of financial resources and the promotion of environmental management. The nature of fiscal policy and the focus of its instruments on

\footnotetext{
* Corresponding author: elenasushkova@ukr.net
} 
economic, social and environmental issues in the life of a country determine the strategic direction for its sustainable development.

Indicators to measure the degree of policy orientation towards the implementation of the country's 17 SDGs, based on the integrated indices of the economy, Social and environmental monitoring of which allows for timely adjustment for effective acceleration of sustainable development of the country. The National List of Indicators for Sustainable Development Goals [1] approved by the Cabinet of Ministers of Ukraine does not contain full indicators that will enable a comprehensive assessment of the direction of the State's fiscal policy towards sustainable development; that the need for their development and the purpose of this study are relevant. In this context, the article proposes a scientific and methodical approach to assessing the level of promotion of fiscal policy of sustainable development, combining a set of indicators of implementation in a country of 17 SDGs. The approach has been tested by measuring the level of promotion of fiscal policy for sustainable development in Ukraine in two scenarios, which will make it possible to forecast the impact of the country's policies.

\section{Literature review}

The emergence of a world policy of sustainable growth began with the challenges of global warming, served as the global adoption of the Sustainable Development Goals in 2015 and the adoption of the UN High-level Political Forum on Sustainable Development (HLPF) under the auspices of the General Assembly on September 24-25, 2019 in New York updated policy areas - 17 Sustainable Development Goals (SDGs). Subsequently, the SDGs summit on October 15, 2019 led to the adoption of the Political Declaration "Gearing up for a decade of action and delivery for sustainable development" [2].

According to the Political Declaration, UN Member States have joined in the development of 100 effective measures to acceleration the implementation of 17 SDGs, have embarked on an inclusive process of adapting the Goals by taking into account the specificities of national development in key economic growth vectors, social justice and environmental management.

On the way to the development of the national model of sustainable development, the scientists pay special attention to budget financing, which begins with the strengthening of funding of the cultural sphere, exactly what Kichurchak, M. [3], Mazur, K., \& Tomashuk, I. [4]. Zabashtansky, M., Zakharin, S., \& Rogovy, A. [5] proposed to strengthen the financing of investment and innovation activities of industrial enterprises that accelerate the process of adaptation to sustainable financial security. Other scholars emphasize the importance of reducing social risks in rural areas to strengthen the tax culture in the context of fiscal policy-making, and are reflected in the work of Gamboa, J., Hurtado, J., \& Ortiz, G. [6], Koroviy, V. [7]. This is reflected in the article on the importance of the mechanism of balance of the budget system from Yushkova, O., Kirina, L., Malis, N., Mandroshchenko, O., and Nazarova, N. [8]. In turn, Fostolovych V.A., Vozyk A.S. [9] argue that fiscal policy is a key driver in government regulation of the efficient use of natural resources. Tulush, L., Radchenko, O., \& Hryshchenko, O. [10] emphasize fiscal stimulation of the population in the context of the ecological component of sustainable development in the rural territories of Ukraine.

Žubule, $\bar{E}$., \& Puzule, A. [11] note that the fiscal space of a country affects the context of sustainable development, and the study of public finance policy allows to identify the scenario of sustainable growth of a country as a whole. Thus, inclusiveness, social inclusion and the level of influence of fiscal policy make it a key driver for achieving sustainable growth. The issue of monitoring the results of fiscal stimulus and assessing the impact of fiscal policy on socio-economic processes is always relevant. The proposed scientific and 
methodological approach to assessing the level of promotion of fiscal policies for sustainable development addresses the set of interrelated institutional elements in the interest of a country's economic, social and environmental growth.

\section{Results and discussion}

Fiscal policy, as a set of interrelated institutional elements, has certain financial interests and needs. Fiscal policy for the promotion of sustainable development is oriented towards the needs and interests of the State and society, with the aim of adapting the next generation to modern conditions with sufficient financial security. Therefore, the indicators of the methodological and scientific approach to the assessment of fiscal policies to promote sustainable development should be considered in the context of the economic, social and environmental performance of a country.

The first pillar is economic growth indicators, which are implemented through important aspects such as poverty alleviation, agricultural development, improvement of social and labour relations, and innovative development of industry and infrastructure, Sustainable growth of cities and communities, high levels of public-private and social partnership. The achievement of social justice is based on the inclusive development of the country and the interests of society and the economic growth of the nation as a whole. This component is being implemented through the provision of quality, accessible education, the promotion of health, the reduction of gender gaps and social infidelity, the establishment of social institutions to ensure justice and the strengthening of linkages. The third pillar of sustainable development is environmental protection, promotion of resource-efficient production, recycling and reduction of emissions. The objective of fiscal policy in this area is to stimulate the environmental behaviour of economic agents by complying with the emission standards for pollutants and rational use of natural resources, thereby reducing the man-made burden on the environment (Table 1).

Table 1. Indicators for assessing the fiscal policy of the state in the context of promoting sustainable development (environmental block).

\begin{tabular}{|c|c|c|}
\hline $\begin{array}{c}\text { Sustainable } \\
\text { development goals }\end{array}$ & Fiscal policy assessment indicators & $\begin{array}{c}\text { Interpretation of } \\
\text { indicators }\end{array}$ \\
\hline $\begin{array}{l}\text { G6. Clean water } \\
\text { and proper } \\
\text { sanitation; } \\
\text { G14. Conservation } \\
\text { of marine resources }\end{array}$ & $\begin{array}{l}\text { The degree of tax incentives for the rational use of water and fish } \\
\text { resources: } \\
\mathrm{I}_{\text {TIRUW }}= \\
\frac{\text { Budget revenues(rent for water,fish })+ \text { Environmental tax }(\text { water })}{\text { Budget expenses for environmental protection }}\end{array}$ & $\begin{array}{l}\text { optimistic scenario } \\
\mathrm{I}_{\text {TIRUW }} \geq 0,500 \\
\text { pessimistic scenario } \\
\mathrm{I}_{\text {TIRUW }}<0,250\end{array}$ \\
\hline $\begin{array}{l}\text { G12. Responsible } \\
\text { consumption and } \\
\text { production }\end{array}$ & $\begin{array}{l}\text { Index of the nature of fiscal incentives for rational use of nature: } \\
\mathrm{I}_{\text {FIRUN }}= \\
\frac{\text { Budget revenues (rent) }+ \text { Environmental tax }}{\text { Budget expenses for environment }+ \text { Enterprise expenses for environment }}\end{array}$ & $\begin{array}{l}\text { optimistic scenario } \\
\mathrm{I}_{\text {FIRUN }}=1,000 \\
\text { pessimistic scenario } \\
\mathrm{I}_{\text {FIRUN }}<0,500\end{array}$ \\
\hline $\begin{array}{l}\text { G15. Protection and } \\
\text { restoration of } \\
\text { terrestrial } \\
\text { ecosystems }\end{array}$ & $\begin{array}{l}\text { The degree of tax incentives for the rational use of terrestrial } \\
\text { ecosystem: } \\
\mathrm{I}_{\mathrm{TIRUTE}}=\frac{\text { Budget revenues(rent for forest })+ \text { Environmental tax }(\text { pollution })}{\text { Budget expenses for environmental protection }}\end{array}$ & $\begin{array}{l}\text { optimistic scenario } \\
\mathrm{I}_{\text {TIRUTE }} \geq 0,500 \\
\text { pessimistic scenario } \\
\mathrm{I}_{\text {TIRUTE }}<0,250\end{array}$ \\
\hline $\begin{array}{l}\text { G7. Available and } \\
\text { clean energy }\end{array}$ & $\begin{array}{l}\text { Index of the nature of fiscal stimulation of rational use of energy } \\
\text { resources: } \\
\mathrm{I}_{\text {FSRUER }}= \\
\quad \text { Budget expenses for development of energy complex } \\
\text { Budget revenues(rent for petroleum,natural gas, gas condensate)+ } \\
\text { Environmental tax(electricity) }\end{array}$ & $\begin{array}{l}\text { optimistic scenario } \\
\mathrm{I}_{\mathrm{FSRUER}} \geq 0,300 \\
\text { pessimistic scenario } \\
\text { I FSRUER }<0,100\end{array}$ \\
\hline $\begin{array}{l}\text { G13. Climate } \\
\text { change mitigation }\end{array}$ & $\begin{array}{l}\text { The degree of tax impact on the level of pollutant emissions: } \\
\mathrm{I}_{\mathrm{TILPE}}=\frac{\text { Environmental tax }}{\text { Budget expenses for environmental protection }}\end{array}$ & $\begin{array}{l}\text { optimistic scenario } \\
\mathrm{I}_{\mathrm{TILPE}}=1,000 \\
\text { pessimistic scenario } \\
\mathrm{I}_{\mathrm{TILPE}} \backslash<0,500\end{array}$ \\
\hline
\end{tabular}


Table 2. Indicators for assessing the fiscal policies of the State in the context of promoting sustainable development (economic bloc).

\begin{tabular}{|c|c|c|}
\hline $\begin{array}{c}\text { Sustainable } \\
\text { development goals }\end{array}$ & Fiscal policy assessment indicators & $\begin{array}{c}\text { Interpretation of } \\
\text { indicators }\end{array}$ \\
\hline $\begin{array}{l}\text { G1. Overcoming } \\
\text { poverty }\end{array}$ & $\begin{array}{l}\text { The level of fiscal constraint on the purchasing power of the } \\
\text { population: } \\
\mathrm{I}_{\mathrm{FCPPP}}=\frac{P I T+\text { Social insurance }+ \text { War pays }}{\text { Total people revenues }}\end{array}$ & $\begin{array}{l}\text { optimistic scenario } \\
\mathrm{I}_{\mathrm{FCPPP}} \leq 0,100 \\
\text { pessimistic scenario } \\
\mathrm{I}_{\mathrm{FCPPP}}>0,400\end{array}$ \\
\hline $\begin{array}{l}\text { G2. Overcoming } \\
\text { hunger, agricultural } \\
\text { development }\end{array}$ & $\begin{array}{l}\text { Index of state influence (due to fiscal instruments) on the } \\
\text { development of agriculture: } \\
\text { ISIDA } \\
\text { Budget revenues (singletax }-4 \text { group) } \\
\text { Budget expenses for development agriculture }\end{array}$ & $\begin{array}{l}\text { optimistic scenario } \\
\mathrm{I}_{\mathrm{SIDA}} \geq 0,800 \\
\text { pessimistic scenario } \\
\mathrm{I}_{\mathrm{SIDA}}<0,400\end{array}$ \\
\hline \multirow[t]{3}{*}{$\begin{array}{l}\text { G8. Decent work } \\
\text { and economic } \\
\text { growth }\end{array}$} & $\begin{array}{l}\text { The level of redistribution of GDP through tax tools: } \\
\mathrm{I}_{\mathrm{RGDPT}}=\frac{\text { Budget revenues }(\text { taxes })}{\text { GDP }}\end{array}$ & $\begin{array}{l}\text { optimistic scenario } \\
\mathrm{I}_{\text {RGDPTT }} \approx 0,350 \\
\text { pessimistic scenario } \\
\mathrm{I}_{\text {RGDPTT }}<0,150\end{array}$ \\
\hline & $\begin{array}{l}\text { The real wage tax rate: } \\
\mathrm{I}_{\mathrm{RWTR}}=\frac{\text { PIT }+ \text { Social insurance }+ \text { War pays }}{\text { Enterprise expenses for wage }}\end{array}$ & $\begin{array}{l}\text { optimistic scenario } \\
\mathrm{I}_{\text {RWTR }}<0,250 \\
\text { pessimistic scenario } \\
\mathrm{I}_{\text {RWTR }} \geq 0,500\end{array}$ \\
\hline & $\begin{array}{l}\text { Index of fiscal stimulation of small and medium-sized business } \\
\text { development: } \\
\text { IFSSMBD = } \\
\qquad P I T(S / M \text { bu } \sin \text { ess })+\text { Social insurance } \\
\text { Budget expenses for small/medium business development }\end{array}$ & $\begin{array}{l}\text { optimistic scenario } \\
\mathrm{I}_{\mathrm{FSSMBD}} \geq 0,500 \\
\text { pessimistic scenario } \\
\mathrm{I}_{\mathrm{FSSMBD}}<0,200\end{array}$ \\
\hline \multirow[t]{2}{*}{$\begin{array}{l}\text { G9. Industry, } \\
\text { innovation and } \\
\text { infrastructure }\end{array}$} & $\begin{array}{l}\text { Index of state support for innovation: } \\
\mathrm{I}_{\mathrm{SSI}}=\frac{\text { Budget expenses for R \& D }}{\text { Total budget expenses }}\end{array}$ & $\begin{array}{l}\text { optimistic scenario } \\
\text { I }_{\text {SSI }} \geq 0,300 \\
\text { pessimistic scenario } \\
\text { I }_{\text {SSI }}<0,100\end{array}$ \\
\hline & $\begin{array}{l}\text { Index of state support for infrastructure modernization: } \\
\mathrm{I}_{\mathrm{SSIM}}=\frac{\text { Budget revenues (parking fee) }+ \text { Property tax }}{\text { Budget expenses for infrastructure modernization }}\end{array}$ & $\begin{array}{l}\text { optimistic scenario } \\
\mathrm{I}_{\mathrm{SSIM}}=1,000 \\
\text { pessimistic scenario } \\
\mathrm{I}_{\mathrm{SSIM}}<0,500\end{array}$ \\
\hline $\begin{array}{l}\text { G11. Sustainable } \\
\text { urban and } \\
\text { community } \\
\text { development }\end{array}$ & $\begin{array}{l}\text { The level of financial (tax) capacity of local authorities: } \\
\mathrm{I}_{\mathrm{TCLA}}=\frac{\text { Localbudget revenues }(\mathrm{t} \text { axes })}{\text { Localbudget expenses }}\end{array}$ & $\begin{array}{l}\text { optimistic scenario } \\
\mathrm{I}_{\text {TCLA }} \geq 0,800 \\
\text { pessimistic scenario } \\
\mathrm{I}_{\text {TCLA }}<0,500\end{array}$ \\
\hline G 17. Partnerships & $\begin{array}{l}\text { The level of financial assistance to foreign countries: } \\
\text { Budget revenues(financial assistance from } \\
\mathrm{I}_{\mathrm{FAFC}}=\frac{\text { donors/foreign countries) }+ \text { Received foreign loans }}{\text { Total budget expenses }}\end{array}$ & $\begin{array}{l}\text { optimistic scenario } \\
\mathrm{I}_{\mathrm{FAFC}}<0,150 \\
\text { pessimistic scenario } \\
\mathrm{I}_{\mathrm{FAFC}} \geq 0,300\end{array}$ \\
\hline
\end{tabular}

Applying the principle of hierarchy of diagnostic knowledge and by analogy with the Voynarenko M. et al. [12], the assessment of the level of support for fiscal sustainable development is presented through the linguistic variable $F p(f)$ and aggregated measures of contribution and implementation factors as $X$ is the environmental cluster of indicators (Table 1); $Y$ is economic (Table 2); $Z$ is social (Table 3 ).

The hierarchical relationship between the state parameters and the level assessment of the promotion of fiscal policies for sustainable development is graphically presented as a tree of the logical conclusion (figure 1.) where the root corresponds to the level of implementation of the SDGs (or acceleration if growth is defined) and where the tops are the constituent indicators of fiscal policy in the directions of implementation. 
Table 3. Indicators for assessing the fiscal policy of the state in the context of promoting sustainable development (social block).

\begin{tabular}{|c|c|c|}
\hline $\begin{array}{c}\text { Sustainable } \\
\text { development goals }\end{array}$ & Fiscal policy assessment indicators & $\begin{array}{c}\text { Interpretation of } \\
\text { indicators }\end{array}$ \\
\hline \multirow[t]{2}{*}{$\begin{array}{l}\text { G3. Good health } \\
\text { and well-being }\end{array}$} & $\begin{array}{l}\text { Level of financial coverage of budget expenses for health care, } \\
\text { spiritual and physical development by individual taxation: } \\
\mathrm{I}_{\mathrm{FCHCPIT}}= \\
\qquad P I T+\text { Social insurance }\end{array}$ & \multirow[t]{2}{*}{$\begin{array}{l}\text { optimistic scenario } \\
\mathrm{I}_{\mathrm{FCHCPIT}}=1,000 \\
\text { pessimistic scenario } \\
\mathrm{I}_{\mathrm{FCHCPIT}}<0,600\end{array}$} \\
\hline & $\overline{\text { Budget expenses for health care, spiritual and physical development }}$ & \\
\hline \multirow[t]{3}{*}{$\begin{array}{l}\text { G4. Quality } \\
\text { education }\end{array}$} & $\begin{array}{l}\text { Level of financial coverage of budget expenses for education } \\
\text { by individual taxation: }\end{array}$ & \multirow{3}{*}{$\begin{array}{l}\text { optimistic scenario } \\
\mathrm{I}_{\mathrm{FCEPIT}}=1,000 \\
\text { pessimistic scenario } \\
\mathrm{I}_{\mathrm{FCEPIT}}<0,600\end{array}$} \\
\hline & $\mathrm{I}_{\mathrm{FCEPIT}}=\frac{P I T}{P}$ & \\
\hline & $\overline{\text { Budget expenses for education }}$ & \\
\hline G5. Gender equality & $\begin{array}{l}\text { Index of the ratio of PIT payment by women and men: } \\
\mathrm{I}_{\mathrm{RPITWM}}=\frac{\mathrm{PIT}(\text { female })}{P I T(\text { male })}\end{array}$ & $\begin{array}{l}\text { optimistic scenario } \\
\mathrm{I}_{\text {RPITWM }}=1,000 \\
\text { pessimistic scenario } \\
\mathrm{I}_{\text {RPITWM }}<0,500\end{array}$ \\
\hline \multirow[t]{3}{*}{$\begin{array}{l}\text { G10. Reducing } \\
\text { inequality }\end{array}$} & $\begin{array}{l}\text { Level of financial coverage of budget expenses for social } \\
\text { protection by individual taxation: }\end{array}$ & \multirow{3}{*}{$\begin{array}{l}\text { optimistic scenario } \\
\mathrm{I}_{\mathrm{FCSPIT}}=1,000 \\
\text { pessimistic scenario } \\
\mathrm{I}_{\mathrm{FCSPIT}}<0,600\end{array}$} \\
\hline & \multirow{2}{*}{$\mathrm{I}_{\mathrm{FCSPPIT}}=\frac{P I T}{\text { Budget expenses for social protection }}$} & \\
\hline & & \\
\hline \multirow[t]{3}{*}{$\begin{array}{l}\text { G16. Peace, justice } \\
\text { and strong } \\
\text { institutions }\end{array}$} & $\begin{array}{l}\text { Level of financial coverage of national functions (higher and } \\
\text { local authorities, financial and foreign policy activities, debt } \\
\text { service, etc.) and defense: }\end{array}$ & \multirow{3}{*}{$\begin{array}{l}\text { optimistic scenario } \\
\mathrm{I}_{\mathrm{FCNFD}}=1,000 \\
\text { pessimistic scenario } \\
\mathrm{I}_{\mathrm{FCNFD}}<0,700\end{array}$} \\
\hline & Budget revenues(taxes) & \\
\hline & $\overline{\text { Budget expenses for national functions }}$ & \\
\hline
\end{tabular}

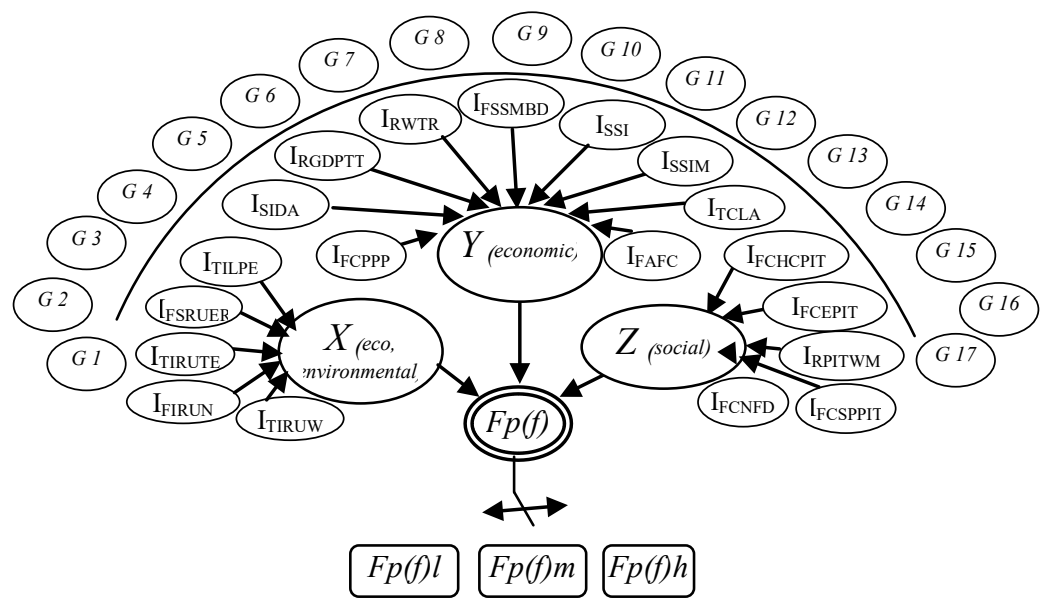

Fig. 1. The tree of the logical conclusion of hierarchical connections of the level of promotion of fiscal policy to sustainable development.

The economic-mathematical model of the overall function of promoting fiscal policy $F p(f)$, reflecting its degree of sustainability, can be expressed in terms of ratios:

$$
\begin{aligned}
& F p(f)=f(X, Y, Z), \\
& X=f\left(G_{6}, G_{14}, G_{12}, G_{15}, G_{7}, G_{13}\right) \\
& Y=f\left(G_{1}, G_{2}, G_{8}, G_{9}, G_{11}, G_{17}\right) \\
& Z=f\left(G_{3}, G_{4}, G_{5}, G_{10}, G_{16}\right)
\end{aligned}
$$


Result $F p(f) l$ ranges from 0 to the indicators of the pessimistic scenario - the country's fiscal policy does not create conditions for the sustainable development of the country; Result $F p(f) m$ is in the range of pessimistic to optimistic scenario - the country's fiscal policy is balanced in terms of ensuring conditions for the sustainable development of the country; Result $F p(f) h$ corresponds to the optimistic scenario and approximates to 1 - fiscal policy contributes to the sustainable development of the country.

In order to systematize and construct the graphic image in the form of a petal diagram in the Excel level of fiscal policy, we accept the condition of mathematical matching of indicators in such a way that everyone strives for maximum. Accordingly, the indicators that are kept to a minimum are translated under the formula $1-\mathrm{n}$. These include the level of fiscal restraint on purchasing power of the population, the real rate of wage tax, the level of financial assistance of foreign countries (Table 4).

Table 4. Dynamics of indicators for assessing the fiscal policy of Ukraine in the context of promoting sustainable development for $2016-2020$.

\begin{tabular}{|c|c|c|c|c|c|c|c|}
\hline \multirow{2}{*}{$\begin{array}{l}\text { № } \\
\text { 3/II }\end{array}$} & \multirow[b]{2}{*}{ Indicators } & \multicolumn{5}{|c|}{ Dynamic } & \multirow{2}{*}{$\begin{array}{c}\text { Changes } \\
2020- \\
2016\end{array}$} \\
\hline & & 2016 & 2017 & 2018 & 2019 & 2020 & \\
\hline \multicolumn{7}{|c|}{ Economic block } & $-12,71 \%$ \\
\hline \multirow[t]{2}{*}{1} & $\begin{array}{l}\text { The level of fiscal constraint on the } \\
\text { purchasing power of the population }\end{array}$ & 0,232 & 0,234 & 0,247 & 0,214 & $0,191^{*}$ & $-17,67 \%$ \\
\hline & Inverted indicator \#1 & 0,768 & 0,766 & 0,753 & 0,786 & 0,809 & $5,34 \%$ \\
\hline 2 & $\begin{array}{l}\text { Index of state influence (due to fiscal } \\
\text { instruments) on the development of } \\
\text { agriculture }\end{array}$ & 0,537 & 0,348 & 0,341 & 0,340 & 0,330 & $-38,55 \%$ \\
\hline 3 & $\begin{array}{l}\text { The level of redistribution of GDP } \\
\text { through tax tools }\end{array}$ & 0,273 & 0,278 & 0,277 & 0,269 & $0,261 *$ & $-4,40 \%$ \\
\hline \multirow[t]{2}{*}{4} & The real wage tax rate & 0,492 & 0,518 & 0,524 & 0,503 & $0,494 * *$ & $0,41 \%$ \\
\hline & Inverted indicator \#4 & 0,508 & 0,482 & 0,476 & 0,497 & 0,506 & $-0,39 \%$ \\
\hline 5 & $\begin{array}{l}\text { Index of fiscal stimulation of SMB } \\
\text { development }\end{array}$ & 0,304 & 0,269 & 0,242 & 0,270 & 0,166 & $-45,39 \%$ \\
\hline 6 & Index of state support for innovation & 0,006 & 0,007 & 0,007 & 0,006 & 0,006 & 0,00 \\
\hline 7 & $\begin{array}{l}\text { Index of state support for infrastructure } \\
\text { modernization }\end{array}$ & 0,531 & 0,376 & 0,308 & 0,336 & 0,212 & $-60,08 \%$ \\
\hline 8 & $\begin{array}{l}\text { The level of financial (tax) capacity of } \\
\text { local authorities }\end{array}$ & 0,424 & 0,410 & 0,408 & 0,478 & 0,597 & $40,80 \%$ \\
\hline \multirow[t]{2}{*}{9} & $\begin{array}{l}\text { The level of financial assistance to } \\
\text { foreign countries }\end{array}$ & 0,078 & 0,099 & 0,091 & 0,059 & 0,157 & $101,28 \%$ \\
\hline & Inverted indicator $\# 9$ & 0,922 & 0,901 & 0,909 & 0,941 & 0,843 & $-8,57 \%$ \\
\hline \multicolumn{7}{|c|}{ Social block } & $+6,44 \%$ \\
\hline 10 & $\begin{array}{l}\text { Index of redistribution of financial } \\
\text { resources at the expense of individual } \\
\text { taxation (for social protection, health } \\
\text { care, education, spiritual and physical } \\
\text { development) }\end{array}$ & 0,489 & 0,551 & 0,705 & 0,679 & 0,578 & $18,20 \%$ \\
\hline 11 & $\begin{array}{l}\text { Index of the ratio of PIT payment by } \\
\text { women and men }\end{array}$ & 0,668 & 0,730 & 0,727 & 0,708 & $0,725 * * *$ & $8,53 \%$ \\
\hline 12 & $\begin{array}{l}\text { Level of financial coverage of national } \\
\text { functions (higher and local authorities, } \\
\text { financial and foreign policy activities, } \\
\text { debt service, etc.) and defense }\end{array}$ & 0,706 & 0,832 & 0,928 & 0,824 & 0,680 & $-3,68 \%$ \\
\hline \multicolumn{7}{|c|}{ Environmental block } & $+2,63 \%$ \\
\hline 13 & $\begin{array}{l}\text { The degree of tax incentives for the } \\
\text { rational use of water and fish resources }\end{array}$ & 0,247 & 0,225 & 0,235 & 0,183 & 0,176 & $-28,74 \%$ \\
\hline 14 & $\begin{array}{l}\text { Index of the nature of fiscal incentives } \\
\text { for rational use of nature }\end{array}$ & 0,751 & 0,696 & 0,775 & 0,920 & $0,905 * *$ & $20,51 \%$ \\
\hline 15 & $\begin{array}{l}\text { The degree of tax incentives for the } \\
\text { rational use of forest resources }\end{array}$ & 0,319 & 0,266 & 0,283 & 0,283 & 0,319 & 0,00 \\
\hline 16 & $\begin{array}{l}\text { Index of the nature of fiscal stimulation } \\
\text { of rational use of energy resources }\end{array}$ & 0,054 & 0,062 & 0,080 & 0,096 & 0,229 & $324,07 \%$ \\
\hline
\end{tabular}




\begin{tabular}{|l|l|l|l|l|l|l|l|}
\hline 17 & $\begin{array}{l}\text { The degree of tax impact on the level of } \\
\text { pollutant emissions }\end{array}$ & 0,797 & 0,639 & 0,597 & 0,626 & 0,596 & $-25,22 \%$ \\
\hline Total index of fiscal policy support $(\boldsymbol{F p}(\boldsymbol{f}))$ & $\mathbf{8 , 3 0 4}$ & $\mathbf{7 , 8 3 8}$ & $\mathbf{8 , 0 5 1}$ & $\mathbf{8 , 2 4 2}$ & $\mathbf{7 , 9 3 8}$ & $\mathbf{- 4 , 4 1 \%}$ \\
\hline
\end{tabular}

* Calculated using the forecast data of the NBU / URL: https://vgolos.com.ua/news/natsbank-otsinyvpadinnya-ekonomiky-ukrayiny-u-2020-rotsi-shho-varto-znaty_1366546.html

** Calculated using preliminary data of the State Statistics Service of Ukraine

** Calculated for the period January-September 2020 according to the State Statistics Service of Ukraine

The results of the calculation of indicators for the evaluation of Ukraine's fiscal policy in the context of promoting sustainable development for 2016 - 2020 are reflected in the dynamics in figure 2 .

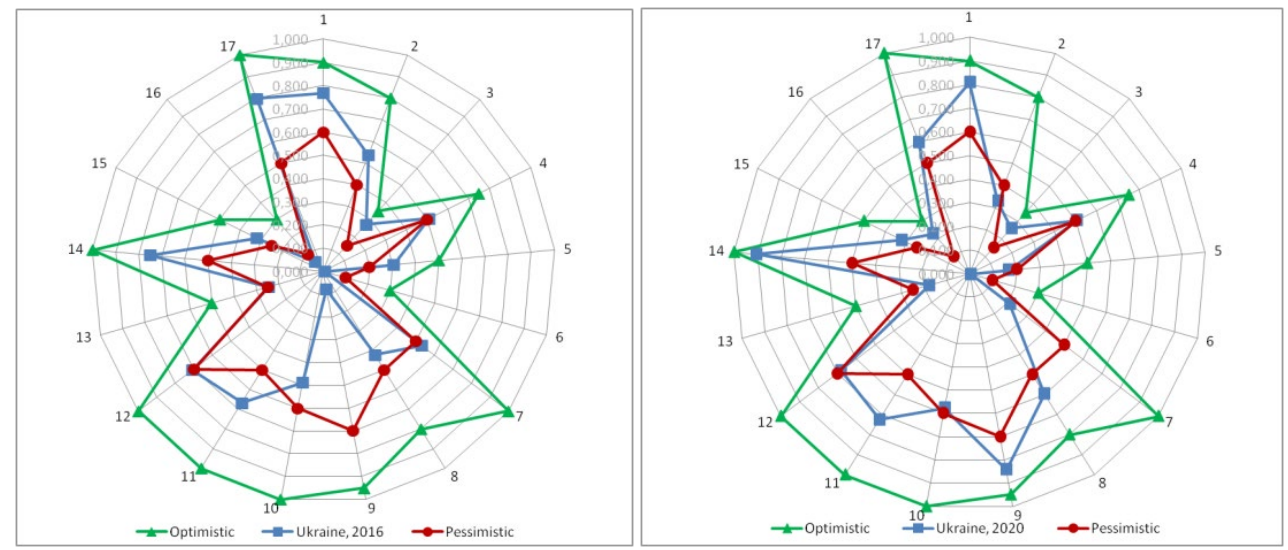

Fig. 2. The level of fiscal policy support for sustainable development of Ukraine in 2016 and 2020

The characteristics of the changes in private indicators indicate a reduction in the position in the economic direction of realization by -12.71 per cent, which does not overlap with positive changes in the environmental $(+2.63$ per cent $)$ and social $(+6.44$ per cent $)$ directions of fiscal policy. Overall, the overall weakening during the study period is -4.41 per cent, meaning that the negative nature of the changes should be emphasized. Indicators of the level of support for fiscal sustainable development policies crossed the threshold of the pessimistic scenario in 2016 at 5 positions, while in 2020 only 3 indicators are in the critical zone and 3 are bordering on those of the pessimistic scenario.

\section{Conclusion}

Finally, in order to assess the level of promotion of fiscal policies for sustainable development, a scientific and methodological approach has been tested based on a set of indicators to help accelerate the implementation of 17 SDGs. Each area of implementation of the concept of sustainable development in the country has its own sources of financial support from the State and local budgets. On this basis, the authors presented the results of the calculation of a set of indicators for the evaluation of fiscal policy with the economic, social and environmental cluster, reflecting the impact of the implementation of the country's fiscal policy in the context of promoting the sustainable development of the country. Based on the results of the mapping in the form of a petal chart, it is shown that the values of the overall trend indicators narrow the scope of the key fiscal policy objectives to accelerate the implementation of 17 SDGs. The characterization of changes in private economic performance determines the weakening of fiscal policy performance, and the aggregate index of fiscal support for sustainable development declines annually. According 
to the results of the study, it has been proved that the level of support for the fiscal policy of sustainable development in Ukraine suppresses the implementation of 17 SDGs, and the nature of the changes tends towards a pessimistic development scenario.

\section{References}

1. Cabinet of Ministers of Ukraine, List of National Indicators for Sustainable Development Goals. Issue of data collection for monitoring the implementation of sustainable development goals (Resolution no. 686-p, 21 August 2019), http://www.ukrstat.gov.ua. Accessed 21 March 2021

2. High-level Political Forum (HLPF) on Sustainable Development under the auspices of the General Assembly. Accelerating the implementation of the 2030 Agenda for Sustainable Development, 24 - 25 September, Ney-York, https://sustainabledevelopment.un.org/sdgsummit. Accessed 21 March 2021

3. M. Kichurchak, Evaluation of the cultural sphere budgetary financing at the subnational level in the context of sustainable development in Ukraine. FCA:PTP, 4(35), 230-237 (2020). https://doi.org/10.18371/fcaptp.v4i35.222063.

4. K. Mazur, I. Tomashuk, Governance and regulation as an indispensable condition for developing the potential of rural areas. BJES. 5(5), 67 (2020). https://doi.org/10.30525/2256-0742/2019-5-5-67-78.

5. M. Zabashtansky, S. Zakharin, A. Rogovy, Financing investment and innovation activities of industrial enterprises in the context of the national economy transition to the sustainable development model. UEB. (45), 184-195 (2020). https://doi.org/10.31470/2306-546x-2020-45-184-195

6. J. Gamboa, J. Hurtado, G. Ortiz, Management of fiscal policy to strengthen tax culture in Ecuador. Revista Publicando. 4(10), 448-461 (2017).

7. V. Koroviy, Tax policy as a component of the budget income formation system. UEB. (43), 152-160 (2019). https://doi.org/10.31470/2306-546x-2019-43-152-160

8. O. Yushkova, L. Kirina, N. Malis, O. Mandroshchenko, N. Nazarova, Tax revenues and balanced budgets. ERSJ, 21(1), 675-686 (2018)

9. V. Fostolovych, A. Vozyk, Essence of environmental taxe in the economic of using natural resources. Economics: collection of scientific works of Vinnytsia National Agrarian University. 4 (70), 175 - 180 (2012)

10. L. Tulush, O. Radchenko, O. Hryshchenko, Fiscal incentives for personal peasants in the context of ecological development of rural territories of Ukraine, in E3S Web of Conferences 203, 5 November 2020, (Vol. 203), 16, 05007 (EDP Sciences, 2020). https://doi.org/10.1051/e3sconf/202020305007

11. E. Žubule, A. Puzule, State fiscal space research formation in the context of sustainable development, in Society. Integration. Education. Proceedings of the International Scientific Conference, May 26th - 27th 2017, Volume IV, 445-455 (2017). https://doi.org/10.17770/sie2017vol4.2348

12. M. Voynarenko, V. Hurochkina, O. Sushkova, I. Yepifanova, Beneficial ownership chain and its evaluation arrangement. Estudios de Economia Aplicada, V. 38-3, N. 1 (2020) 